Cakrawala Dini: Jurnal Pendidikan Anak Usia Dini | p-ISSN 2087-I317 | e-ISSN 262I-8321

Vol.Il No.2 November 2020 | Hal 155-166

\title{
KELEBIHAN PROGRAM FULL DAY PADA PENDIDIKAN ANAK USIA DINI
}

\author{
Siyyella Tika ${ }^{1}$, Pujiyanti Fauziah $^{2}$ \\ 1,2 Universitas Negeri Yogyakarta
}

\begin{abstract}
A full-day school program is a school choice that can accommodate the conditions of parents who have long working hours. The purpose of this article is to provide insight and information to readers, PAUD educators, education activists, and parents about planning good parental assistance to send schools to the program with full-day schools)and half-day schools. The method used in the discussion of this article is the study of literature. The results of this study are comparing half-day schools (half-day schools) or regular schools usually program, full-day schools have more advantages, such as being able to help improve the development of various fields of children, emotional social abilities, receptive language skills, and elementary school preparation skills. More importantly, a full-day school that provides parenting programs is involved in several child-managed activities to help parents find ways, for example parenting through teachers at school.
\end{abstract}

Keyword: Parent Involvment, Full day school, Half day school, Kindergarden

\begin{abstract}
Abstrak: Program full day school (sekolah sehari penuh) merupakan pilihan sekolah yang dapat mengakomodir kondisi kedua orang tua yang memiliki jam kerja panjang. Tujuan dari penulisan artikel ini adalah memberikan wawasan dan informasi kepada para pembaca, pendidik PAUD, penggiat pendidikan, dan orang tua tentang pentingnya keterlibatan orang tua yang baik yang menyekolahkan anaknya di sekolah dengan program full day school (sekolah sehari penuh) maupun half day school (sekolah setengah hari). Metode yang digunakan dalam penulisan artikel ini adalah studi literatur. Hasil penelitian ini yaitu dibandingkan half day school (sekolah setengah hari) atau sekolah reguler biasanya program, full day schooll (sekolah sehari penuh) memiliki keuntungan yang lebih, seperti dapat membantu meningkatkan pengembangan berbagai bidang kemampuan anak yakni, kemampuan sosial emosinal, keterampilan bahasa reseptif, dan keterampilan kesiapan memasuki sekolah dasar. Yang lebih penting full day school (sekolah sehari penuh) yang menyediakan program parenting dimana orang tua dilibatkan dalam beberapa kegiatan anak disekolah dapat membantu orang tua mendapatkan cara, contoh pengasuhan anak melalui guru di sekolah.
\end{abstract}

Kata Kunci: Keterlibatan orang tua, Program Full Day dan Half Day, Anak Usia Dini

\footnotetext{
'Universitas Negeri Yogyakarta, Email: Siyyellatika.2019回student.uny.ac.id

${ }^{2}$ Universitas Negeri Yogyakarta, Email: Pujiyanti国uny.ac.id
} 


\section{PENDAHULUAN}

Usia dini merupakan periode yang rentan bagi anak. Pada usia dini, semua anak tumbuh dan berkembang dengan pesat. Oleh karenanya usia dini disebut dengan "golden age" yang berarti, masa ini merupakan periode yang sangat berharga. Sehingga anak harus mendapat stimulasi yang cukup dan sesuai dengan tahap perkembangannya karena setiap anak memiliki proses tahap perkembangan yang berbeda-beda.

Selaras dengan pendapat Mutiah (Purnanti, 2014) yang menyebutkan bahwa anak usia dini merupakan makhluk hidup dengan proses pertumbuhan dan perkembangan yang berbeda bahkan unik. Artinya, setiap aspek perkembangan dan pertumbuhan anak secara umum memiliki tahapan yang sama namun hasil pencapaian pada setiap aspek perkembangan setiap anak akan berbeda. Hal ini sejalan dengan ungkapan Piaget (Mutiah, 2012) yang menyatakan anak lahir dengan segala potensi dan keunikan mereka yang berbeda-beda, bahkan anak kembar sekali pun akan memiliki perbedaan.

Sebagian besar waktu anak berada di rumah,sehingga keberhasilan stimulasi terhadap pertumbuhan dan perkembangannya tidak hanya bergantung pada program-program belajar yang ada disekolah tetapi juga perlu dukungan penuh dari keluarga terutama orang tua. Pandangan orang tua bahwa pendidikan diserahkan sepenuhnya kepada guru dan sekolah harus diluruskan. Stimulasi pada pendidikan anak usia dini khususnya tentu merupakan kerjasama antara guru di sekolah dan orang tua.

Dewasa ini pendidikan anak usia dini sudah menjadi prioritas penting bagi orang tua. Apalagi bagi ayah dan ibu yang memiliki jam kerja panjang. Sehingga mereka memilih sekolah yang dapat mengakomodir kondisi ini. Kemudian juga banyak sekolah taman kanak-kanak yang sudah menerapkan program full day schooll (sekolah sehari penuh) walaupun begitu tetap ada sekolah yang menerapkan half day scholl atau sekolah reguler biasanya.

Full day school (sekolah sehari penuh) adalah proses pembelajaran yang diberlakukan dari pagi hingga sore hari dengan berbagai jadwal kegiatan yang telah dirancang sedemikian rupa dilakukan mulai pukul 06.45-15.00 dengan waktu istiharat setiap 2 jam sekali sedangkan half day scholl adalah sekolah setengah hari yang berlangsung dari pagi sampai siang (Baharudin, 2010).

Dengan adanya program full day school (sekolah sehari penuh) memberikan kesempatan kepada anak untuk lebih banyak mendapat pengalaman belajar disekolah bersama guru dan teman-teman sekolah. Tambahan waktu atau jam sekolah pada program full day school (sekolah sehari penuh) dapat memberikan kesempatan kepada guru untuk lebih maksimal dalam usaha penanaman karakter pada anak usia dini. Selain itu juga dapat memberikan keleluasaan pada guru dalam mengembangkan dan melaksanakan ideide kreatif metode pembelajaran untuk anak karena memiliki waktu yang lebih banyak.

Namun yang terjadi, peran orang tua yang menyekolahkan anaknya di sekolah dengan program full day school (sekolah sehari penuh) justru makin berkurang khususnya di daerah perkotaan dimana kebanyakan kedua orang tua bekerja dengan jam kerja yang panjang. Ditambah lagi dengan adanya fenomena yang tengah trend di masyarakat yakni peningkatan jumlah ibu bekerja sehingga sekolah dengan program full day school menjadi alternatif pilihan sekolah yang paling diminati.

Menurut data statistik angka partisipasi pendidikan di Indonesia yang dilihat berdarakan jenis kelamin pada tingkat SMA pada tahun 2011 menunjukkan angka yang seimbang antara pria dan wanita. Dimana wanita 
memiliki angka persentase $48,31 \%$ dan pria memiliki presentase $47,64 \%$ (Puji Yanti Fauziah, 2016). Hal ini menunjukkan bahwa wanita dan pria nantinya akan memiliki kesempatan bekerja yang sama dan tentu secara tidak langsung akan berdampak pada perubahan kondisi keluarga terutama keluarga yang memiliki anak usia dini. Tentu kondisi keluarga yang kedua orang tua atau ayah dan ibu sama-sama bekerja di luar rumah dengan jam kerja panjang harus memberikan alternatif pengasuhan kepada anak selama orang tua bekerja. Sehingga sekolah dengn program full day menjadi salah satu pilihan yang dianggap paling baik.

Namun para orang tua justru cenderung menyerahkan sepenuhnya pendidikan anak mereka kepada guru di sekolah. Padahal walaupun begitu orang tua tetap harus terlibat dan memberikan pengasuhan yang cukup untuk anak. Orang tua merasa anak sudah cukup mendapat pengasuhan disekolah dengan program full day school (sekolah sehari penuh). Dengan demikian peran pengasuhan orang tua terhadap anak kurang dilakukan dengan maksimal.

Disisi lain program half day school atau sekolah reguler cenderung menjadikan peran pengasuhan orang tua jauh lebih kuat karena waktu anak sebagain besar dihabiskan dirumah. Sehingga waktu bersama orang tua akan lebih banyak. Namun, ini tidak menjamin bahwa semua orang tua akan menjalankan peran pengasuhan nya secara maksimal, karena masih banyak didapati orang tua yang menyekolahkan anaknya di sekolah reguler atau half day school tetap saja tidak maksimal menjalankan peran pengasuhan selama anak dirumah. Saat pulang sekolah anak dibiarkan bermain bebas tanpa arahan dari orang tua.

Terlebih lagi dibandingkan dengan full day scholl (sekolah sehari penuh) yang cenderung dipilih oleh orang tua dengan status ekonomi atau sosial menengah ke atas dikarenakan biaya sekolah yang cukup tinggi, program half day school (sekolah setengah hari) lebih banyak diminati oleh orang tua dengan status ekonomi menengah ke bawah karena biaya sekolah yang lebih terjangkau. Sehingga juga terdapat kesenjangan antara sekolah dengan full day school dengan half day school.

Program sekolah Full day school (sekolah sehari penuh) yang memiliki tambahan jam sekolah dapat lebih maksimal dalam menstimulasi dan memberikan penanaman karakter pada anak yang juga berdampak pada biaya sekolah yang cukup tinggi. Hal ini menyebabkan hanya oramg tua dengan status ekonomi menengah keatas yang mampu menyekolahkan anak mereka ke sekolah full day scholl (sekolah sehari penuh). Sehingga orang tua dengan status ekonomi menengah ke bawah lebih memilih half day school yang biaya sekolah yang lebih terjangkau, namun dengan capaian hasil perkembangan anak yang secara umum tidak semaksimal full day school (sekolah sehari penuh).

Terlepas dari orang tua yang menyekolahkan anak mereka di sekolah dengan program full day school maupun half day school, keterlibatan kedua orang tua dalam pengasuhan anak harus tetap semaksimal mungkin. Keterlibatan kedua orang tua yang maksimal dalam pengasuhan anak akan mempengaruhi pertumbuhan dan pekembangannya. Karena salah satu kunci keberhasilan program disekolah untuk menstimulasi perkembangan anak juga didukung oleh keterlibatan pengasuhan orang tua pada anak-anaknya.

Berdasarkan hal tersebut maka dapat diajukan dalam artikel ini adalah bagaimana program full day school (sekolah sehari penuh) dan half day school (sekolah setengah hari) mempengaruhi perkembangan anak usia dini? dan bagaimana keterlibatan orang tua yang menyekolahkan anaknya di 
sekolah dengan program full day school dan half day school?.

Tujuan dari penulisan artikel ini adalah untuk memberikan wawasan dan informasi kepada para pembaca, pendidik PAUD, penggiat pendidikan, dan orang tua tentang pentingnya keterlibatan orang tua yang baik yang menyekolahkan anaknya di sekolah dengan program full day school (sekolah sehari penuh) maupun half day school (sekolah setengah hari).

\section{METODOLOGI PENELITIAN}

Metodologi yang digunakan dalam penulisan artikel ini adalah studi literatur. Artikel ini berisi kajian literatur tentang keterlibatan orang tua dalam program full day (sekolah sehari penuh) dan half day school (sekolah setengah hari) anak usia dini yang dikaji dari berbagai macam sumber pustaka.

Tujuan penggunaan metode studi literatur ini untuk langkah pertama dalam membuat perencanaan penelitian dengan memanfaatkan berbagai kajian pustaka untuk memperoleh data dilapangan.

Sumber yang menjadi rujukan dalam penulisan artikel ini adalah berbagai macam sumber seperti jurnal baik nasional maupun internasional, laporan penelitian dan data hasil penelitian, peraturan dasar hukum, buku, dan lain-lain.

Kemudian sumber yang menjadi rujukan akan menjadi landasan pemikiran dalam penulisan artikel ini. Maka langkah yang dilakukan selanjutnya adalah mensintesis gagasan ataupun ide solusi dari berbagai masalah yang ada pada sumber rujukan yang dikumpulkan secara sistematis. Sehingga dengan hal tersebut diharapkan menjadi solusi terbaik yang dapat diberikan dan ditampilkan untuk para cendikia dalam lingkungan civitas akademika pendidikan anak usia dini.

\section{HASIL PENELITIAN DAN PEMBAHASAN}

Dewasa ini pendidikan anak usia dini sudah mengikuti perkembangan zaman dan bergerak menjauh dari kendala dan hambatan-hambatan pada pendidikan anak usia dini yang terbilang tradisional. Lingkungan belajar yang lebih berbasis bermain dan berpusat pada anak dimana anak berinteraksi dengan lingkungan belajar sesuai kecepatan perkembangannya masing-masing. Agar anak-anak usia dini kedepannya mampu mengahdapi dan menyesuaikan diri dengan perubahan lingkungan yang terus berkembang maka diperlukannya inovasi pemebalajaran yang mampu mengakomodasi hal tersebut. Meskipun inovasi pembelajaran anak usia dini sangat membantu, tetap harus memperhatikan dan mempertimbangkan kondisi, dan aspek perkambangan anak yang berbeda-beda sehingga dapat menjangkau seluruh anak dengan proses perkembangan yang berbeda-beda.

Salah satu program pada zaman modern ini adalah full day school (sekolah sehari penuh) memberikan kesempatan bagi seluruh anak untuk belajar konsep akademik dan ketermapilan sosial melalui bermain dan eksplorasi berbeda dengan program half day school (sekolah setengah hari) yang betujuan untuk mendidik anak melalui latihan kelompok yang diarahkan guru dan dirancang utnuk membiasakan anak dengan kerasnya peraturan (Kaitlyn Heagle, 2017).

Full day school (sekolah sehari penuh) adalah program sekolah yang mana menyediakan waktu akademik di sekolah yang cukup panjang dari pada program sekolah pada umumnya atau sekolah reguler (Maksudin,2013:18). Konsep full day school (sekolah sehari penuh) ini tidak menambah materi belajar yang dapat memberatkan anak namun merupakan tambahan jam sekolah yang dimanfaatkan untuk pengayaan materi dengan metode belajar PAIKEM( 
Pembelajaran Aktif, Inovatif, Kreatif, Efektif dan Menyenangkan) untuk menambah pengetahuan dan wawasan bagi anak serta sebagai kesempatan pembentukan karakter anak-anak.

\section{Baharudin}

berpendapat Full (sekolah sehari penuh) day school adalah sebuah program sekolah dimana kegiatan pembelajaran dilakukan sepanjang hari atau dari pagi hari hingga sore hari dimulai dari pukul 06.45-15.00 WIB dengan waktu istirahat dilakukan setiap 2 jam sekali dengan berbagai jadwal kegiatan yang telah dirancang sedemikian rupa. Sedangkan half day scholl (sekolah setengah hari) merupakan program sekolah setengah hari atau sekolah reguler yang mana kegiatan pembelajaran dilakukan dari pagi hingga siang hari yang tidak memuat program tambahan secara khusus.

Pelletier (2014) menyebutkan tujuan dari program sekolah sehari penuh adalah untuk memberikan manfaat jangka panjang terhadap proses perkembangan anak dan memberikan dasar yang kuat untuk belajar di lingkungan berbasis bermain yang aman dan mendukung dimana keterampilan fisik motorik, soisal emosional, dan kognitif semua anak dapat distimulasi lebih maksimal.

Manfaat sekolah sehari penuh yang dilaporkan Langford \& Santo.A (2016) dari hasil penemuannnya meliputi prestasi akdemik yang lebih tinggi, masa transisi yang lebih mudah dilewati anak saat memasuki jenjang pendidikan sekolah dasar, perpanjangan waktu untuk meningkatkan pengalaman belajar, dan peningkatan keterampilan sosial.

Anak-anak yang bersekolah di sekolah sehari penuh memiliki presentase waktu belajar dan bermain yang bebas aktif yang lebih besar dibandingkan dengan anak-anak di sekolah setengah hari yang menghabiskan lebih banyak waktu dalam kelompok besar yang diarahkan oleh guru dan cenderung kaku
(Janette Patricia, 2018). Hal ini semakin menegaskan bahwa tambahan waktu atau jam sekolah pada program sekolah sehari penuh digunakan untuk memberikan stimulasi yang lebih kepada anak.

Selain itu program sekolah sehari penuh memberikan lebih banyak kesempatan bagi anak-anak untuk berinteraksi, bekerja sama dengan anakanak lain, memupuk keterampilan sosialisasi dan hubungan dengan teman sebaya (Heagle \& Timmons, 2017). Tidak hanya dari segi akademik tambahan waktu atau jam sekolah pada sekolah sehari penuh artinya dapat membantu meningkatkan berbagai keterampilan sosial anak.

Sejalan dengan hal ini Cooper \& Allen (2010) juga menemukan hasil yang sama bahwa anak-anak dengan sekolah sehari penuh dinilai memiliki perilaku kelas yang lebih positif yaitu, belajar mandiri, keterlibatan kelas yang aktif, dapat bekerja sama dengan teman sebaya serta perilaku negatif yang lebih sedikit seperti, merasa cemas dan menarik diri. Melalui sekolah sehari penuh ini tentunya merupakan manfaat ataupun kelebihan yang mampu mengurangi berbagai macam perilaku kelas yang kurang baik.

Hal tersebut juga didukung oleh dalam hasil temuan Diamond.A \& Barnett (2011) yang menyebutkan sekolah sehari penuh memberikan banyak peluang untuk anak dapat bermain sosiodrama yang kompleks dimana anak terlibat dalam kerja sma dan percakapan panjang dengan teman sebaya nya tanpa gangguan yang dilaporkan dapat membantu pengembangan keterampilan sosial dan konsep diri anak.

Sementara itu menurut Fesseha \& Pyle (2016) banyak guru yang mendukung sekolah sehari penuh karena dapat memberikan kesempatan kepada guru dalam menanamkan keterampilan literasi yang lebih maksimal dengan adanya tambahan waktu atau jam sekolah. Bagi orang tua yang memiliki 
jam kerja panjang dan tidak memiliki waktu luang mungkin hal ini akan membantu dalam menstimulasi kemampuan atau keterampilan literasi awal pada anak mereka.

Selaras dengan penemuan Gary E. Bingham (2013) yang meneliti keefektifan pengalaman belajar sekolah sehari penih dan setengah hari pada hasil akademik anak yang menunjukkan bahwa anak-anak dalam program sehari penuh menunjukkan keuntungan pada pencapaian kosa kata, melek huruf dan kemampuan kognitifnya dibanding dengan anak-anak yang bersekolah setengah hari (half day school) atau sekolah reguler.

Tidak hanya tingkat melek huruf yang lebih tinggi pada anak-anak dengan program sekolah sehari penuh, tetapi seluruh manfaat ini terus berjalan sebagai keuntungan jangka panjang bagi tahuntahun selanjutnya pendidikan anak (Pelletier \& Patel,2018)

Allison Atteberry (2019) juga menegaskan full day school (sekolah sehari penuh) juga membawa pengaruh positif kepada keterampilan kosa kata reseptif anak sehingga secara tidak langsung juga meningkatkan keterampilan kesiapan sekolah anak.

Reynolds (2014) membandingkan hasil penilaian dari anak-anak yang menghadiri program full day school (sekolah sehari penuh) dengan anak-anak half day school (sekolah setengah hari) dimana, anak-anak dalam sekolah sehari penuh mendapat skor yang lebih tinggi pada 4 dari 6 indikator kesiapan masuk sekolah dasar, termasuk pengembangan bahasa, sosial emosional, kognitif dan kesehatan fisik. Namun penulis mengingatkan bahwa mungkin hasil ini bias karena anak-anak memiliki kecepatan perkembangan yang berbedabeda satu sama lain.

Namun pandangan lain ditemukan

pada penyataan Cannon,J.S \& Jacknowitz (2011) bahwa di negara USA program full day school (sekolah sehari penuh) merupakan salah satu alternatif program pendidikan yang ditargetkan untuk anak-anak minoritas, terutama mereka yang berstatus bahasa Inggris sebagai bahasa kedua, hal ini bertujuan untuk memperbaiki kesenjangan capaian hasil perkembangan antara anak yang bahasa pertama nya bahasa Inggris dengan anak-anak yang bahasa Inggris sebagai bahasa kedua mereka.

Hall Kenyon \& Bingham (2009) menemukan bahwa anak-anak dalam program sekolah sehari penuh, memiliki penilaian yang lebih tinggi dalam pengetahuan alfabet, bunyi huruf, pengejaan dan pengenalan kata terlepas dari status bahasa mereka, temuan ini menyebutkan fakta bahwa sekolah sehari penuh sangat mempengaruhi pengembangan bahasa anak namun tidak ada perbedaan dalam pengembangan pengetahuan matematika anak-anak dengan sekolah setengah hari atau sekolah reguler.

Perbandingan antara sekolah sehari penuh dengan sekolah setengah hari, para guru telah mencatat bahwa sekolah hari penuh menawarkan manfaat pendidikan seperti peningkatan dan fleksibilitas dalam perencanaan kurikulum dan penjadwalan harian, integrasi topik tematik yang lebih lengkap, diskusi mendalam antara guru dan anak-anak, peluang untuk intervensi yang diperlukan dan instruksi individual untuk anak-anak dan sosialisasi diantara anak-anak (Michelle Marie,2018).

Dapat dipahami bahwa program sekolah sehari penuh memberikan keleluasaan bagi guru dalam mengimprovisasikan metode dan kegiatan-kegiatan belajar untuk anak, selain itu hubungan anak-anak dengan teman-temannya akan terjalin lebih erat. Bauernschuster \& Schlotter (2015) menyebutkan bahwa selain dampak langsung sekolah sehari penuh untuk proses pembelajaran anak program sehari penuh yang memfasilitasi program yang melibatkan orang tua dengan jam kerja 
panjang untuk terlibat pada beberapa kegiatan anak di sekolah maupun program-program parenting yang disediakan sekolah yang mana hal tersebut dapat membantu praktik pengasuhan orang tua pada anak yang bermanfaat bagi perkembangan anak.

Orang tua yang terlibat penuh dalam pengasuhan anak pada usia dini akan menjadikan hubungan yang erat antara orang tua dan anak (Retnaningtyas, 2015). Hubungan yang erat ini tentunya merupakan kesempatan bagi orang tua untuk membangun komunikasi yang baik antara orang tua dan anak. Terlebih jika kedua orang tua yang tidak menghabiskan banyak waktu dirumah karena bekerja hubungan erat ini merupakan kunci agar orang tua dapat tetap berkomunikasi secara maksimal dengan anak.

Program full day school (sekolah sehari penuh) mengatasi meningkatnya kebutuhan pendidikan anak usia dini yang berkualitas dan mengatasi dinamika kehidupan keluarga dimana ibu juga bekerja dengan jam kerja yang panjang sama halnya seperti ayah, sehingga dengan adanya program sekolah sehari penuh membantu para keluarga yang kedua orang tuanya bekerja (Brownell,2015).

Arthur J. Reynolds (2015) menyebutkan bahwa sekolah sehari penuh memiliki hubungan yang positif yang dapat mempengaruhi perkembangan kesiapan membaca anak, peningkatan kehadiran anak disekolah dan keterlibatan orang tua yang cukup baik melalui kegiatan-kegiatan disekolah yang melibatkan orang tua. Artinya dengan adanya program sekolah sehari penuh ini dapat selain dapat mempengaruhi berbagai aspek perkembangan anak juga orang tua dapat ikut terlibat dalam berbagai kegiatan sekolah sehingga ini merupakan kesempatan bagi orang tua untuk melihat apa saja yang dilakukan anak selama mengikuti sekolah sehari penuh.
Parental involvment (keterlibatan orang tua) merupakan bentuk partisipasi kedua orang tua dalam mendidik anak mereka dengan menunjukkan keterikatan, komitmen dan dedikasi dalam pendidikannya untuk membantu anak dalam mencapai seluruh tugas perkembangannya (Hornby, 2011). Khususnya usia dini sangat membutuhkan keterliabatan kedua orang tua dalam mendampingi dan membimbing mereka untuk dapat memaksimalkan perkembangan dan pertumbuhannya.

Keterlibatan orang tua telah didefinisikan secara umum sebagai upaya orang tua untuk mengambil peran aktif dalam pendidikan anak-anak mereka (Sad.S.N, 2012). Bryk (2010) Juga menyoroti keterlibatan orang tua sebagai faktor penting dalam 3 dimensi utama yakni, komunikasi dengan sekolah, partisipasi dalam kegiatan sehari-hari di sekolah, dan partisipasi dalam tata kelola sekolah.

Johnson \& Hull (2014) mencatat bahwa keterlibatan oarng tua terhadap pendidikan anak mereka berkaitan erat dengan peningkatan prestasi anak disekolah. Artinya keterlibatan orang tua dalam pengasuhan untuk anak di usia dini sangatlah dibutuhkan.

Berdasarkan pembahasan diatas, dapat kita pahami bahwa full day school (sekolah sehari penuh) memiliki banyak kelebihan bila dibandingkan dengan half day school (sekolah setengah hari).

Di sisi lain program setengah hari juga memiliki sisi positif nya yakni memberikan anak waktu bermain di luar yang lebih banyak, sehingga interaksi nya dengan lingkungan sekitar khususnya lingkungan rumah lebih banyak. Namun banyak guru yang beranggapan bahwa mereka kekurangan waktu dalam melaksanakan pembelajaran yang bervariasi karena membutuhkan waktu yang lebih leluasa agar materi belajar ataupun materi bermain yang diberikan dapat benar-benar diserap oleh anak. 
Meskipun full day school (sekolah sehari penuh) identik dengan program sekolah yang memiliki biaya yang cukup mahal, namun bagi orang tua yang ingin memberikan pengalaman sekolah yang maksimal kepada anak mereka program ini dapat menjadi salah satu pilihan. Terlebih bagi kedua orang tua yang meiliki jam kerja panjang full day school (sekolah sehari penuh) ini dapat membantu mereka.

Di berbagai negara program full day school (sekolah sehari penuh) sudah cukup dikenal dan sudah banyak dilaksanakan pada pendidikan anak usia dini. Seperti disebutkan sebelumnya program full day school (sekolah sehari penuh) di negara USA merupakan salah satu alternatif program pendidikan yang ditargetkan untuk anak-anak minoritas, terutama mereka yang berstatus bahasa Inggris sebagai bahasa kedua, hal ini bertujuan untuk memperbaiki kesenjangan capaian hasil perkembangan antara anak yang bahasa pertama nya bahasa Inggris dengan anak-anak yang bahasa Inggris sebagai bahasa kedua mereka.

Di Indonesia khususnya, full day school (sekolah sehari penuh) juga sudah diketahui dengan baik oleh para orang tua. Secara umum para orang tua di Indonesia juga memiliki jam kerja yang panjang, oleh karenanya sekolah sehari penuh juga cukup diminati oleh para orang tua.

Secara umum tambahan jam sekolah pada program full day school (sekolah sehari penuh) di Indonesia diisi oleh program day care atau menyerupai penitipan anak. Program tersebut dimodifikasi tidak hanya sebagai program penitipan anak, namun di dalam program tersebut anak diberikan kegiatan belajar non akademik untuk tatp dapat menstimulasi seluruh aspek perkembangannya.

Selanjutnya program sekolah sehari penuh dapat membantu guru dalam menerapkan model kegiatan belajar yang lebih menarik dan bervariasi karena dengan adanya tambahan waktu anakanak benar-benar dapat memilih kegiatan yang sesuai dengan kebutuhan mereka. Selain itu program ini juga dapat membantu kedua orang tua yang samasama bekerja sehingga tidak khawatir tentang anak mereka. Hanya saja penerapannya tergantung tujuan, situasi dan kondisi sekolah itu sendiri apakah mampu melaksanakan program tersebut atau tidak. Karena program sekolah sehari penuh perlu disosialisasikan terlebih dahulu kepada orang tua, mengenai apa saja yang dilakukan anak selama di sekolah seharian penuh dan pencapaian apa yang diharapkan dengan dilaksanakannya program sekolah sehari penuh tersebut.

Program sekolah taman kanakkanak sehari penuh dan setengah hari memiliki kelebihan nya masing-masing. Program sehari penuh sangat mendukung tujuan dari pendidikan anak usia dini dengan adanya tambahan waktu yang lebih panjang dapat lebih menstimulasi seluruh potensi anak, bukan hanya aspekaspek perkembangan namun juga keterampilan kecakapan hidup. Guru juga dapat mengeksplorasi bermacam-macam kegiatan yang menarik dan bervariasi dengan manajemen waktu yang lebih banyak. Selain itu dari perspektif ayah ibu yang sama-sama bekerja, program ini sangatlah membantu mereka, karena mereka tidak khawatir mengenai anak mereka yang ditinggal saat bekerja karena sudah berada di sekolah bersama guru.

Kelebihan dari program Full day
school (sekolah sehari penuh) dibandingkan dengan half day school (sekolah setengah hari) atau sekolah reguler biasa. Selain dapat mengakomodir kondisi orang tua yang memiliki jam kerja panjang, sekolah sehari penuh disebutkan dapat membantu pengembangan berbagai aspek perkembangan anak. Diantaranya, perkembangan sosial emosional yang 
meningkat pada anak-anak yang sekolah sehari penuh. Sekolah sehari penuh memiliki cukup jam tambahan diamana anak dapat mengeskplorasi keterampilan sosial nya dengan beriteraksi dengan guru dan teman sebaya nya tanpa gangguan.

Selain itu juga disebutkan sekolah sehari penuh membantu meningkatkan keterampilan bahasa reseptif anak, melalui interaksi saat sekolah sehari penuh anak mendapat pengalamanpengalaman yang membantu anak dalam memperoleh pengetahuan kosa kata dan cara berkomunikasi yang lebih baik.

Selanjutnya diabanding half day school (sekolah setengah hari) atau sekolah reguler, Full day school (sekolah sehari penuh) membantu pengembangan kesiapan anak dalam memasuki sekolah dasar. Terakhir yang tidak kalah penting adalah Full day school (sekolah sehari penuh) yang menyediakan program parenting dimana orang tua dilibatkan dalam beberapa kegiatan anak disekolah dapat membantu orang tua mendapatkan cara, contoh pengasuhan anak melalui guru di sekolah.

Program sekolah sehari penuh juga harus diisi oleh kegiatan-kegaiatn tambahan seperti parenting. Orang tua yang bekerja rata-rata memiliki waktu yang lebih sedikit dirumah bersama anak mereka. Dengan adanya sekolah sehari penuh ini memang dapat membantu kondisi para orang tua tersebut. Apalagi beberapa pandangan orang tua yang menyerahkan sepenuhnya pendidikan anak mereka kepada guru dan sekolah harus diluruskan. Dengan adanya program Full day school (sekolah sehari penuh) bukan berarti orang tua lepas tangan dan tidak maksimal untuk terlibat dalam pengasuhan anak. Namun tetap saja keterlibatan orang tua dalam pengasuhan anak dan komunikasi oarang tua terhadap pendidikan anak sangatlah penting. Tanpa dukungan dari kedua orang tua, maka apupun program pendidikan yang diberikan kepada anak akan menadapat hasil yang kurang maksimal.

Kemudian keterlibatan orang tua di sekolah dapat membantu meningkatkan keeratan hubungan antara anak dan orang tua. Sehingga apapun program yang dipilih orang tua baik Full day school (sekolah sehari penuh) maupun half day school (sekolah setengah hari) keterlibatan orang tua di dalamnya merupakan kunci keberhasilan semua program tersebut.

Program sekolah sehari penuh memiliki beberapa kelebihan lain yaitu: pemanfaatan waktu dan aktivitas kelompok kecil yang lebih efektif oleh program sehari penuh, tidak terdapat perbedaan yang signifikan dalam tingkat kelelahan anak dengan program sehari penuh dan setengah hari, anak dengan program sehari penuh mendapat banyak peningkatan di bidang sosial, anak dengan program sehari penuh tampil lebih baik dalam keterampilan seni, bahasa dan matematika, orang tua dan guru sama-sama lebih puas dengan program sekolah sehari penuh,tingkat kehadiran anak sama baiknya bahkan lebih baik pada program sekolah sehari penuh, program sehari penuh menguntungkan anak dari latar belakang sosial ekonomi rendah, program sehari penuh menguntungkan bagi anak dari kelompok minoritas, Keluarga dengan orang tua lengkap maupun orang tua tunggal yang semuanya bekerja pada siang hari mendukung program sehari penuh.

Program sehari penuh yang dirancang dengan baik, dan tidak memberikan terlalu banyak tekanan pembelajaran yang bersifat akademik kepada anak tidak membahayakan anak ataupun menyebabkan anak kelelahan.

Karena beberapa orang tua mengalami kekhawatiran pada saat anak sekolah sehari penuh akan menimbulkan kejenuhan dan kelelahan. Oleh karenanya tambahan jam sekolah dimanfaatkan untuk pengayaan materi dengan metode 
belajar PAIKEM ( Pembelajaran Aktif, Inovatif, Kreatif, Efektif dan Menyenangkan) sehingga anak merasa bahagia meskipun sekolah sehari penuh.

Terlepas dari Full day school (sekolah sehari penuh) maupun half day school (sekolah setengah hari) atau sekolah reguler biasa, memperhatikan minat, kebutuhan dan tahap-tahap perkembangan anak adalah faktor yang harus dipertimbangkan oleh orang tua. Baik Full day school (sekolah sehari penuh) maupun half day school (sekolah setengah hari) atau sekolah reguler biasa, tentunya memiliki kelebihan masingmasing dan dapat dipilih sesuai dengan situasi dan kondisi para orang tua. Yang tidak kalah pentng adalah peran serta, keterlibatan orng tua dalam pengasuhan anak merupakan kunci untu mendukung program-program yang dapat membantu meningkatkan perkembangan dan pertumbuhan anak.

\section{KESIMPULAN}

Dewasa ini program Full day school (sekolah sehari penuh) merupakan pilihan sekolah bagi orang tua yang memiliki jam kerja panjang. Terlebih sudah banyak ibu yang juga ikut bekerja dengan jam kerja panjang, sehingga membutuhkan sekolah yang dapat mengakomodir kondisi mereka.

Pada pembahasan diatas sudah banyak disebutkan kelebihan dari program Full day school (sekolah sehari penuh) diabndingkan dengan half day school (sekolah setengah hari) atau sekolah reguler biasa. Selain dapat mengakomodir kondisi orang tua yang memiliki jam kerja panjang, sekolah sehari penuh disebutkan dapat membantu pengembangan berbagai aspek perkembangan anak. Diantaranya, perkembangan sosial emosional yang meningkat pada anak-anak yang sekolah sehari penuh. Sekolah sehari penuh memiliki cukup jam tambahan diamana anak dapat mengeskplorasi keterampilan sosial nya dengan beriteraksi dengan guru dan teman sebaya nya tanpa gangguan.

Selain itu juga disebutkan sekolah sehari penuh membantu meningkatkan keterampilan bahasa reseptif anak, melalui interaksi saat sekolah sehari penuh anak mendapat pengalamanpengalaman yang membantu anak dalam memperoleh pengetahuan kosa kata dan cara berkomunikasi yang lebih baik.

Program sehari penuh yang dilaksanakan dengan menggunakan metode belajar PAIKEM (Pembelajaran Aktif, Inovatif, Kreatif, Efektif dan Menyenangkan) yang dirancang dengan baik dan tidak memberikan terlalu banyak tekanan pembelajaran yang bersifat akademik kepada anak tidak membahayakan anak ataupun menyebabkan anak kelelahan.

Selain itu guru juga dapat mengeksplorasi bermacam-macam kegiatan yang menarik dan bervariasi dengan manajemen waktu yang lebih banyak. Selain itu dari perspektif ayah ibu yang sama-sama bekerja, program ini sangatlah membantu mereka, karena mereka tidak khawatir mengenai anak mereka yang ditinggal saat bekerja karena sudah berada di sekolah bersama guru.

Selanjutnya dibanding half day school (sekolah setengah hari) atau sekolah reguler, Full day school (sekolah sehari penuh) membantu pengembangan kesiapan anak dalam memasuki sekolah dasar. Terakhir yang tidak kalah penting adalah Full day school (sekolah sehari penuh) yang menyediakan program parenting dimana orang tua dilibatkan dalam beberapa kegiatan anak disekolah dapat membantu orang tua mendapatkan cara, contoh pengasuhan anak melalui guru di sekolah.

Kemudian keterlibatan orang tua di sekolah dapat membantu meningkatkan keeratan hubungan antara anak dan orang tua. Sehingga apapun program yang dipilih orang tua baik Full day school (sekolah sehari penuh) 
maupun half day school (sekolah setengah hari) keterlibatan dan pengasuhan orang tua yang maksimal di dalamnya merupakan kunci keberhasilan semua program tersebut. Terlepas dari Full day school (sekolah sehari penuh) maupun half day school (sekolah setengah hari) atau sekolah reguler biasa, memperhatikan minat, kebutuhan dan tahap-tahap perkembangan anak adalah faktor yang harus dipertimbangkan oleh orang tua. Inilah salah satu alasan perlunya keterlibatan orang tua. Karena orang tua yang paling mengerti kebutuhan anak mereka.

\section{DAFTAR PUSTAKA}

Allison Atteberry. (2019). The Effects Of Full Day Kinfergarten:

Ezperimental Evidence Of Impacts On Children's School Resdiness. Educational Evaluation and policy analysis. DOI: 10.3102/0162373719872197

Bauernschuster, S., \& Schlotter, M. (2015). Public Child Care And Mothers' Labor SupplyEvidence From Two QuasiExperiments. Journal of Public Economics, 123, 1-16

Brownell, M. D., Nickel, N. C., Chateau, D., Martens, P. J., Taylor, C., Crockett, L., Goh, C. Y. (2015). Long-Term Benefits Of Full-Day Kindergarten: A Longitudinal Population-Based Study. Early Child Development and Care, 185(2), 291-316.

Bryk, A. S., P. B. Sebring, E. Allensworth, S. Luppescu, and J. Q. Easton. (2010). Organizing Schools for Improvement: Lessons from Chicago. Chicago, IL: University of Chicago Press. Doi: $10.1177 /$ 0895904815586848.

Cannon, J. S., Jacknowitz, A., \& Painter, G. (2011). The Effect Of Attending Full-Day Kindergarten
On English Learner Students. Journal of Policy Analysis and Management, 30(2), 287-309.

Cooper, H., Allen, A.B., Patall, E.A., \&

Dent, A.L. (2010). Effects Of Full-Day Kindergarten On Academic Achievement And Social Development. Review of Educational Research, 80, 34-70.

Fesseha, E., \& Pyle, A. (2016). Conceptualising Play-Based Learning From Kindergarten Teachers' Perspectives. International Journal of Early Years Education, 24(3), 361-377.

Gary E. Bingham \& Kendra M. HallKenyon (2013) Full- And HalfDay Kindergarten Programmes: Examining Impacts On Second Language Learners, Early Child Development and Care, 183:2, 185-199, DOI: 10.1080/03004430.2012.662227

Heagle, K., Timmons, K., Hargreaves, F., \& Pelletier, J. (2017). The Social Kindergartener: Comparing Children's Perspectives Of FullAnd Half-Day Kindergarten. Early Child Development and Care, 187(5-6), 978-989.

Hornby, G, Parental Involvement In Childhood Education: Building Effective School Family Partnership. (2011). New York:Springer Sciencet Bussiness Media, 25

Janette Patricia Pelletier \& James E. Corter (2019): A Longitudinal Comparison of Learning Outcomes In Full-Day And HalfDay Kindergarten. The Journal of Educational Research, DOI: 10.1080/00220671.2018.1486280

Johnson, U. Y., and D. M. Hull. 2014. Parent Involvement And Science Achievement: A Cross-Classified Multilevel Latent Growth Curve Analysis. The Journal of Educational Research 107 (5): 399-409. 
doi:10.1080/00220671.2013.8074 88.

Kaitlyn Heagle, Kristy Timmons, Fabienne Hargreaves \&Janette Pelletier. (2017) The Social Kindergartener:Comparing

Children's Perspective Of Full And Half Day Kindergarten. Early Child Development and Care DOI: 10.1080/03004430.2016.1199551

Langford, R. D., Santo, A., Valeo, A., Underwood, K., \& Lenis, A. (2016). The innovation of Ontario full-day kindergarten educator teams: have they reproduced the split systems of care and education? Gender and Education, 1-18

Maksudin, Pendidikan Islam Alternatif Membangun Karakter Melalui Sistem Boarding School, (Yogyakarta: UNY Press, 2013). Hal. 18

Michelle Marie Lau. (2018) Is whole day kindergarten better than half day indergarten? Amixed methods study of chinese educator's perceptions. Children and Youth Service.

DOI:10.1016/j.childyouth.2018.0 7.007

Mutiah, Diana (2012). Psikologi Bermain Nak Usia Dini. Jakarta: Kencana Predana Media Group

Pelletier, J. (2014). Ontario's full-day kindergarten: A bold public policy initiative. Public Sector Digest, June Issue: Education, 41-49.

Pelletier, J., \& Patel, S. (2018). Full-day kindergarten: Longitudinal effects on children's educational success and well-being. Insight Research Grant: Social Sciences and Humanities Research Council of Canada (2015-2020). Grant \# 435-2015-0441. Ottawa, Ontario, Canada.
Puji Yanti Fauziah. (2016). Pemetaan Mutu PAUD FULLDAY Untuk Meningkatan Kualitas Layanan dan Kelembagaan Program PAUD. Jurnal Penelitian dan Evaluasi Pendidikan, 20(1),70-79

Retnaningtyas, M.S. (2015) Keterlibatan Orang Tua Dalam Pendidikan Anak Di TK Anak Ceria. Jurnal Psikologi Pendidikan dan Perkembangan, 4(1), 9-17.

Reynolds, A. J., Richardson, B. A., Hayakawa, M., Lease, E. M., Warner-Richter, M., Englund, M. M., Sullivan, M. (2014). Association Of A Fullday Vs PartDay Preschool Intervention With School Readiness, Attendance, And Parent Involvement. Journal of the American Medical Association, 312, 2126-2134.

Sad, S. N. (2012). Investigation of Parental Involvement Tasks As Predictors Of Primary Students' Turkish, Math, And Science \& Technology Achievement. Eurasian Journal of Educational Research 49: 173-196.

Timmons, K., Pelletier,J., \& Corter,C. (2016). Understanding Children's Self-Regulation Within Different Classroom Contexts. Early Child Development and Care, 186(2), 249-267. 